\title{
Food for thought: Risks of non-native species transfer to the Antarctic region with fresh produce
}

\author{
Kevin A. Hughes ${ }^{a}$,*, Jennifer E. Lee ${ }^{b}$, Megumu Tsujimoto ${ }^{c, d}$, Satoshi Imura ${ }^{e}$, Dana M. Bergstrom ${ }^{f}$, \\ Chris Ware $^{\mathrm{f}}$, Marc Lebouvier ${ }^{\mathrm{g}}$, Ad H.L. Huiskes ${ }^{\mathrm{h}}$, Niek J.M. Gremmen ${ }^{\mathrm{h}}$, Yves Frenot ${ }^{\mathrm{i}}$, Paul D. Bridge ${ }^{\mathrm{j}}$, \\ Steven L. Chown ${ }^{\text {b }}$
}

${ }^{a}$ British Antarctic Survey, Natural Environment Research Council, High Cross, Madingley Road Cambridge CB3 OET, UK

${ }^{\mathrm{b}}$ Centre for Invasion Biology, Department of Botany and Zoology, Stellenbosch University, Private Bag X1, Matieland 7602, South Africa

${ }^{\mathrm{c}}$ The Graduate University for Advanced Studies, Tokyo, Japan

d Japan Society for the Promotion of Science, Tokyo, Japan

e National Institute of Polar Research, Tokyo, Japan

${ }_{\mathrm{f}}^{\mathrm{f}}$ Australian Antarctic Division, Department of the Environment, Water, Heritage and the Arts, 203 Channel Highway, Kingston 7050, Australia

${ }^{\mathrm{g}}$ CNRS, University of Rennes 1, Station Biologique, 35380 Paimpont, France

${ }^{\mathrm{h}}$ Netherlands Institute of Ecology, P.O. Box 140, 4400 AC Yerseke, The Netherlands

${ }^{\mathrm{i}}$ French Polar Institute Paul Emile Victor, Plouzané, France

${ }^{j}$ CABI Bioservices, Bakeham Lane, Egham, Surrey, TW20 9TY, UK

\section{A R T I C L E I N F O}

\section{Article history}

Received 7 December 2010

Received in revised form 16 February 2011

Accepted 1 March 2011

Available online 26 March 2011

\section{Keywords:}

Alien

Non-indigenous

Biosecurity

Propagules

Food

Polar

Antarctica

Sub-Antarctic

\begin{abstract}
A B S T R A C T
To understand fully the risk of biological invasions, it is necessary to quantify propagule pressure along all introduction pathways. In the Antarctic region, importation of fresh produce is a potentially high risk, but as yet unquantified pathway. To address this knowledge gap, $>11,250$ fruit and vegetables sent to nine research stations in Antarctica and the sub-Antarctic islands, were examined for associated soil, invertebrates and microbial decomposition. Fifty-one food types were sourced from c. 130 locations dispersed across all six of the Earth's inhabited continents. On average, $12 \%$ of food items had soil on their surface, $28 \%$ showed microbial infection resulting in rot and more than 56 invertebrates were recorded, mainly from leafy produce. Approximately $30 \%$ of identified fungi sampled from infected foods were not recorded previously from within the Antarctic region, although this may reflect limited knowledge of Antarctic fungal diversity. The number of non-native flying invertebrates caught within the Rothera Research Station food storage area was linked closely with the level of fresh food resupply by ship and aircraft. We conclude by presenting practical biosecurity measures to reduce the risk of non-native species introductions to Antarctica associated with fresh foods.
\end{abstract}

(c) 2011 Elsevier Ltd. All rights reserved.

\section{Introduction}

Global economies are increasingly dependent on the movement of goods, people and services on large spatial scales across both political and geographic boundaries (Drake and Lodge, 2004; Vezina, 2005; Jacks and Pendakur, 2008; Procheş et al., 2008). Amongst the many goods which are now routinely transported, fresh produce has perhaps the widest reach and the shortest transport time. A typical meal may include produce from as many as twenty different species from 12 plant families from all eight global centres of cultivated plant diversity (Procheş et al., 2008). With each transport event comes the risk of transporting non-native species. By

\footnotetext{
* Corresponding author. Tel.: +44 1223 221616; fax: +44 1223362616.

E-mail address: kehu@bas.ac.uk (K.A. Hughes).
}

their very nature, foods are potentially viable biological organisms and are transported in ways specifically designed to prolong their longevity in a viable state so that they remain both attractive to human consumers and suitable for consumption. This is achieved either by rapid transportation (often by aircraft) or by storage at cool temperatures. However, methods that enhance the integrity of fresh foods during transit may also enhance the likelihood of survival of associated non-native species such as invertebrates, fungi and other microorganisms.

Antarctica is currently the least invaded continent on the planet. However, in recent years, factors facilitating the introduction and establishment of non-native species within the Antarctic Treaty area have increased. The number of visitors to the region is increasing almost exponentially: tourists and national Antarctic programme personnel now spend a total of $c$. 700,000 person days ashore in the region each year (Jabour, 2009). With a few notable 
exceptions, most research stations and popular areas for tourism are located at coastal sites, often at relatively low latitudes as these sites commonly have attributes which favour human settlement such as ice free ground, shelter from strong winds and a topography that results in a favourable microclimate (Poland et al., 2003; Hull and Bergstom, 2006; Lamers, 2009). However, these attributes also favour the establishment of non-native species (Frenot et al., 2005). A further factor placing the Antarctic region at increasing risk from non-native species introductions is rapid climate change in some areas. Across the northern and western Antarctic Peninsula (an area that already has the least severe climate within the continent) and to a lesser degree over other areas of Antarctica (Turner et al., 2005; Steig et al., 2009) temperatures have increased by as much as $0.5{ }^{\circ} \mathrm{C}$ per decade, with much of the warming taking place in the winter months (Jones, 1995; King and Comiso, 2003; Vaughan et al., 2003; Turner et al., 2005, 2007). At many sub-Antarctic islands temperatures are likewise increasing (Bergstrom and Chown, 1999). As a result, at least from the perspective of temperate species, local environmental conditions are more favourable now than in the past, thereby increasing the likelihood of establishment by species introduced by both natural and anthropogenic mechanisms. Indeed, recent establishment of several plant species in the maritime Antarctic bear out this suggestion (Chwedorzewska, 2008; Molina-Montenegro et al., 2010; Smith and Richardson, 2011).

The recognition of the potential threat of non-native species has led to the investigation of pathways of introduction into the region in association with cargo, vehicles, visitors' clothing, and personal equipment (Whinam et al., 2005; Lee and Chown, 2009a,b; Hughes et al., 2010a,b; SCAR, 2010). Although some nations have implemented precautionary bans on fresh produce (e.g. Marion and Prince Edward Island; Heard Island), little information exists on the risks of non-native species introductions associated with the importation of fresh foods into Antarctica, with the notable exception of the consideration of likely disease risks (reviewed in Kerry and Riddle, 2009; Hughes and Convey, 2010). Fresh foods imported regularly to Antarctic include fruits, vegetables and eggs. Meat is generally supplied frozen, with long-term storage at $-20^{\circ} \mathrm{C}$ likely to kill most introduced macro-organisms. Fruits and vegetables, in particular, may have non-Antarctic soil on their surfaces, while non-native invertebrates and microbial decomposers may exist on an item's surface and/or interior. Soil in particular may contain non-native invertebrates, plant propagules and a high density and diversity of microorganisms (Hughes et al., 2010a). Soil has already been identified as a risk by Parties to the Antarctic Treaty system, and the Protocol on Environmental Protection to the Antarctic Treaty (signed 1991, came into force 1998; also known as the Environmental Protocol or Madrid Protocol) states that 'the importation of non-sterile soil shall be avoided to the maximum extent practicable' [Annex II, Appendix C].

Understanding the biosecurity risks posed by importation of fresh produce to the Antarctic is vital if appropriate guidelines on selection, transportation and storage of fresh foods and disposal of fresh food waste are to be developed. Such guidelines are valuable not only to Antarctic systems but can be applied in a global context.

\section{Methods}

\subsection{Study locations}

Fresh food examinations were undertaken at research stations located in the Antarctic and sub-Antarctic or at pre-departure ports associated with the UK, Australian, South African, French and Japanese Antarctic research programmes (Fig. 1). Antarctic research stations included Rothera Research Station, Rothera Point, Adelaide Island, Antarctic Peninsula (UK: 67³ $34^{\prime} \mathrm{S}, 68^{\circ} 08^{\prime} \mathrm{W}$ ), Syowa Station, East Ongul Island, Lutzow-Holm Bay, East Antarctica (Japan: $69^{\circ} 00^{\prime} \mathrm{S}, 39^{\circ} 35^{\prime} \mathrm{E}$ ), and SANAE IV, Vesleskarvet nunatak, Dronning Maud Land, East Antarctica (South Africa: $71^{\circ} 40^{\prime} S 2^{\circ} 51^{\prime} \mathrm{W}$ ). SubAntarctic research stations included Port-aux-Français, Îles Kerguelen (France: $49^{\circ} 21^{\prime} \mathrm{S}, 70^{\circ} 13^{\prime} \mathrm{E}$ ) and the more northerly Martin de Viviès, Île Amsterdam (France: $37^{\circ} 41^{\prime} \mathrm{S}, 77^{\circ} 31^{\prime} \mathrm{E}$ ). At each location, examination of the food occurred within $48 \mathrm{~h}$ of its arrival on station. Examination of fresh foods sent to the Australian research stations Casey $\left(66^{\circ} 17^{\prime} \mathrm{S} 110^{\circ} 31^{\prime} \mathrm{E}\right)$, Davis $\left(68^{\circ} 35^{\prime} \mathrm{S} 77^{\circ} 58^{\prime} \mathrm{E}\right)$, Mawson $\left(67^{\circ} 36^{\prime} \mathrm{S} 62^{\circ} 52^{\prime} \mathrm{E}\right)$ in East Antarctica and sub-Antarctic Macquarie Island $\left(54^{\circ} 30^{\prime} \mathrm{S} 158^{\circ} 57^{\prime} \mathrm{E}\right)$ was undertaken at the Hobart Ports Facility warehouse, Tasmania, before export.

\subsection{Soil, mould and invertebrates associated with food}

More than 11,250 items of fruit and vegetable, sent to nine research stations in Antarctica and the sub-Antarctic islands, were examined to quantify (1) the amount of soil present (categories: none, $0-1 \mathrm{~g}$ or $>1 \mathrm{~g}$ ), (2) the extent of any fungal infection (categories: $0 \%, 1-25 \%, 26-50 \%, 51-75 \%, 76-100 \%$ of the item's surface area) and (3) the number of associated invertebrates. To gather general information about the importation of foods, for each national operator records were made of the following: imported fruit or vegetable type, number of boxes received on station, transit time (days), whether the produce was refrigerated in transit and the packing material.

\subsection{Identification of fungi}

Samples of decomposed material were taken from fruits and vegetables at Rothera Research Station and Syowa Station. Decomposed material from Syowa Station, was returned to Japan and underwent DNA extractions from pure colonies cultured on potato dextrose agar (PDA) using the Isoplant II kit (Nippon Gene, Tokyo, Japan) (Johnston and Booth, 1983). Following amplification of the ITS regions using primers ITS1F and ITS4B, PCR products were purified using a QIAquick PCR Purification Kit (Qiagen K. K., Tokyo, Japan), sequences were read by PRISM 3100 (ABI) and compared to the DNA Data Bank of Japan (DDBJ) using FASTA (http://www. ebi.ac.uk/Tools/sss/fasta/). At Rothera Research Station, fungi from the sampled material were cultured on PDA at $\sim 20^{\circ} \mathrm{C}$ and returned to the UK at $4{ }^{\circ} \mathrm{C}$ for identification. Cultures sent to the UK were initially identified to group by examining slides from the original plates. Cultures were sub-cultured onto malt agar and DNA was extracted in microLYSIS-PLUS buffer (Microzone Ltd, Haywards Heath, UK). Total ITS regions were amplified using primers TW81 (forward) and AB28 (reverse) (Curran et al., 1994), sequenced and compared to the EMBL Nucleotide Sequence Database collection by BLAST (http://blast.ncbi.nlm.nih.gov/Blast.cgi).

Identifications were made on the basis of coverage, identity score, e value and assessment of reference taxa. In coming to a final name, the top matches for reliable reference strains and peer-reviewed publications were checked. Searches of the British Antarctic Survey 'List of non-lichenized fungi from the Antarctic region' (available at http://www.antarctica.ac.uk/bas_research/data/access/fungi/Speciespublic2.html; Bridge et al., 2008) were undertaken to determine if each isolated fungal species had previously been recorded from the Antarctic region.

\subsection{Flying invertebrates transported with fresh food}

Three electric flying insect killers, each with $2 \times 10$ W UV lamps, were installed in the food bays at Rothera Research Station to quantify the number of non-native flying insects present in food 


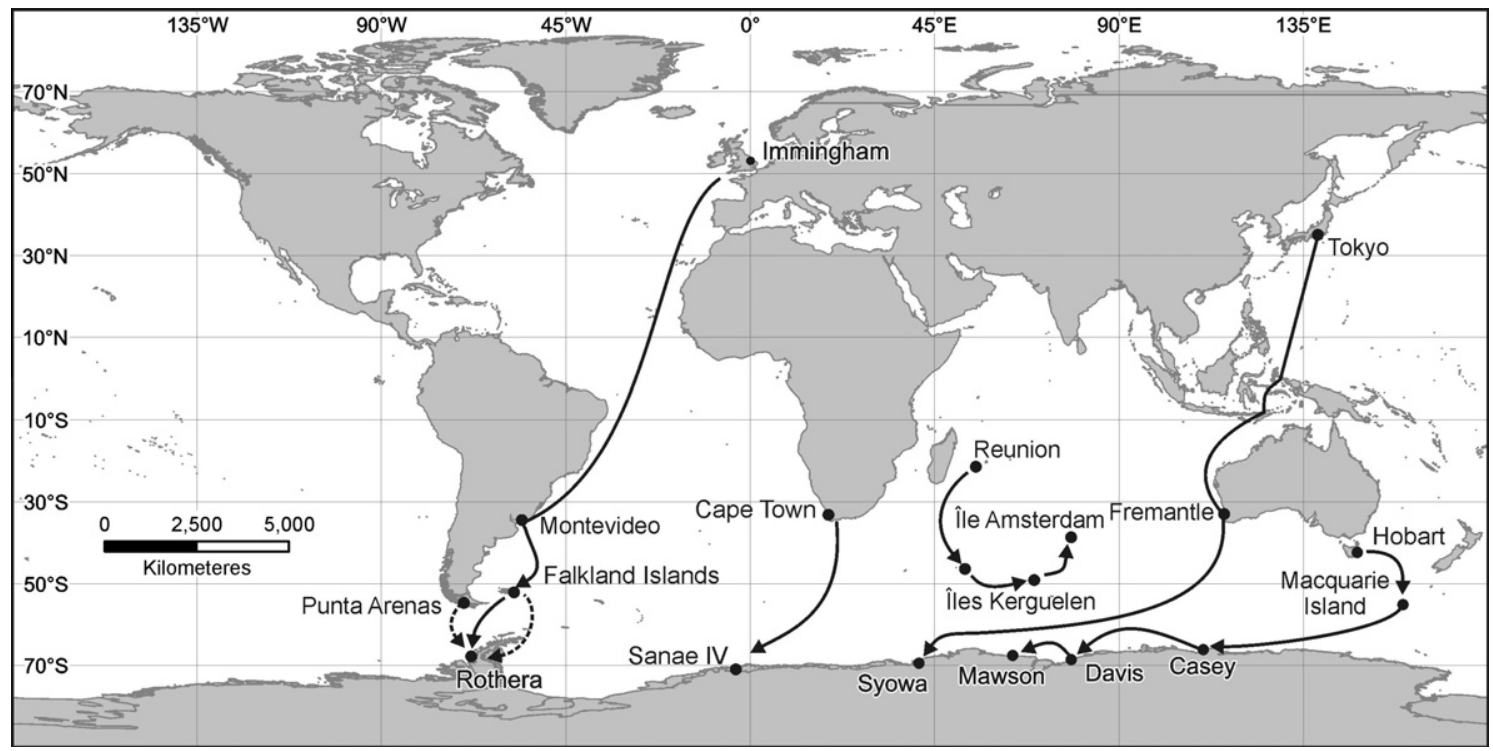

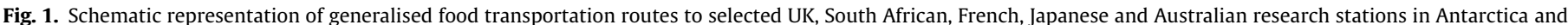
the sub-Antarctic islands [sea routes $(-)$, air routes $(---)$ ].

bays. The numbers of flying insects caught in the devices were recorded each month between March 2005 and September 2006. The duration of air operations to Rothera, during which time fresh foods were transported to the station from South America and the Falkland Islands, and dates when the station was resupplied with fresh foods by ship, were recorded.

\section{Results}

\subsection{Transport of food to stations in the Antarctic region}

Fifty-one varieties of fresh produce from c. 130 locations throughout the world were transported into the Antarctic region (i.e. apples, aubergines, avocadoes, bananas, beetroots, broccoli, butternut squash, red and green cabbage, red and green capsicums, carrots, cauliflowers, celery, chillies, choko, courgettes, cucumbers, eggs, garlic, ginger, grapefruit, grapes, leeks, round and iceberg lettuces, kiwi fruit, lemons, limes, mangoes, mandarin oranges, honeydew, cantaloupe and water melons, mint, onions, oranges, parsley, parsnips, paw paws, peaches, pears, pineapples, plums, potatoes, pumpkins, radishes, sweet potatoes, thyme, tomatoes, and turnips). In all but two cases, food was transported to Antarctica by ship rather than aircraft (Fig. 1; Table 1). The frequency of station resupply by ship varied between once and c. 5 times per year, with the sub-Antarctic stations visited year-round and the Antarctic station visits limited to the austral summer. Food transit time from the port where foods were supplied varied typically from $2 \mathrm{~d}$ to $c$. 7 weeks, depending upon the ship itinerary and distance between the port and Antarctic station. Transportation of foods by aircraft was more rapid (5-6 h) and overall less frequent than transportation by ship.

\subsection{Soil, mould and invertebrates associated with food}

Soil was found on $12 \%$ of all items surveyed, although typically in small quantities $(<1 \mathrm{~g})$ (Table 2$)$. More than 56 invertebrates were found from a range of taxa including: Gastropoda (Pulmonata),

Table 1

Transportation of fresh foods to Antarctic and sub-Antarctic stations during the 2007/08 season.

\begin{tabular}{|c|c|c|c|c|c|c|}
\hline $\begin{array}{l}\text { Station } \\
\text { (capacity }^{\mathrm{a}} \text { ) }\end{array}$ & $\begin{array}{l}\text { Antarctic } \\
\text { biogeographic zone }\end{array}$ & $\begin{array}{l}\text { Importation } \\
\text { method }\end{array}$ & Transit time from port & Resupply season & $\begin{array}{l}\text { Resupply visits } \\
\text { per year }\end{array}$ & $\begin{array}{l}\text { Food } \\
\text { refrigerated }\end{array}$ \\
\hline \multirow[t]{2}{*}{ Rothera (130) } & Maritime & Ship & $\begin{array}{l}>2 \mathrm{~d} \text { from the Falkland Islands, more from } \\
\text { South American ports }{ }^{b}\end{array}$ & December to April & 2 & Yes \\
\hline & & Air & $\begin{array}{l}5-6 \mathrm{~h} \text { from the Falkland Islands or Punta } \\
\text { Arenas }\end{array}$ & October to March & c. 10 & No \\
\hline SANAE IV (80) & Continental & Ship & 4-5 weeks from Cape Town & December & 1 & Yes \\
\hline $\begin{array}{l}\text { Port-aux- } \\
\quad \text { Français } \\
\quad(120)\end{array}$ & Sub-Antarctic & Ship & $\begin{array}{l}13 \mathrm{~d} \text { from La Réunion Is., via Crozet } \\
\text { archipelago }\end{array}$ & $\begin{array}{l}\text { November, December, } \\
\text { April, August }\end{array}$ & 4 & Yes \\
\hline $\begin{array}{l}\text { Martin de Viviès } \\
\text { (35) }\end{array}$ & Sub-Antarctic & Ship & $\begin{array}{l}22 \mathrm{~d} \text { from La Réunion Is., via Crozet } \\
\text { archipelago and Kerguelen Is. }\end{array}$ & $\begin{array}{l}\text { November, December, } \\
\text { April, August }\end{array}$ & 4 & Yes \\
\hline Casey (70) & Continental & Ship & $8 \mathrm{~d}$ from Hobart ${ }^{b}$ & November to April & c. 3 & Yes \\
\hline Mawson (60) & Continental & Ship & $12 \mathrm{~d}$ from Hobart ${ }^{\mathrm{b}}$ & November to March & $1-2$ & Yes \\
\hline Davis (70) & Continental & Ship & $11 \mathrm{~d}$ from Hobart ${ }^{b}$ & November to March & c. 3 & Yes \\
\hline $\begin{array}{l}\text { Macquarie Is. } \\
\quad(40)\end{array}$ & Sub-Antarctic & Ship & $4 \mathrm{~d}$ from the Hobart & Year-round & c. 5 & Yes \\
\hline Syowa (110) & Continental & Ship & $\begin{array}{l}7-8 \text { weeks from Tokyo } \\
3-4 \text { weeks from Fremantle }\end{array}$ & December & 1 & Yes \\
\hline
\end{tabular}

a Maximum number of personnel on station.

b Typically longer (2-5 weeks) if part of a general cruise. 
Table 2

Soil and macro-invertebrate importation into the Antarctic region on fresh foods.

\begin{tabular}{|c|c|c|c|c|c|c|c|}
\hline \multirow[t]{2}{*}{ Nation } & \multirow[t]{2}{*}{ Station } & \multirow{2}{*}{$\begin{array}{l}\text { No. of fresh } \\
\text { foods } \\
\text { types } \\
\text { examined }\end{array}$} & \multirow{2}{*}{$\begin{array}{l}\text { No./weight of } \\
\text { food } \\
\text { items checked }\end{array}$} & \multicolumn{3}{|c|}{ Soil present on food items } & \multirow{2}{*}{$\begin{array}{l}\text { Macro-invertebrates found on } \\
\text { checked food items (No. and status) }\end{array}$} \\
\hline & & & & $\begin{array}{l}\text { No soil } \\
(0 \mathrm{~g})\end{array}$ & $\begin{array}{l}\text { Some } \\
\text { (c. } 0-1 \mathrm{~g})\end{array}$ & $\begin{array}{l}\text { Much } \\
(>1 \mathrm{~g})\end{array}$ & \\
\hline United Kingdom & $\begin{array}{l}\text { Rothera Research } \\
\text { Station }\end{array}$ & 37 & 3608 & $83.4 \%$ & $16.6 \%$ & $0 \%$ & $\begin{array}{l}\text { Total: } 12 \text {. Slug ( } 1: \text { alive), earwigs ( } 2: \text { alive), spiders } \\
\text { ( } 3: 1 \text { dead, } 2 \text { alive), snails ( } 2: \text { alive), weevil ( } 1: \text { dead), } \\
\text { flies ( } 2: \text { alive), beetle ( } 1: \text { alive) }\end{array}$ \\
\hline South Africa & SANAE IV & 19 & 1430 & $95.2 \%$ & $4.5 \%$ & $0.3 \%$ & None recorded \\
\hline \multirow[t]{2}{*}{ France } & Port-aux-Français, & 31 & 1965 & $88.6 \%$ & $11.3 \%$ & $0.1 \%$ & $\begin{array}{l}\text { Total: } 12+\text {. Butterfly ( } 2 \text { ), caterpillar ( } 3 \text { ), snails ( } 2 \text { ), } \\
\text { spider ( } 1 \text { ), slug ( } 1 \text { ), weevil ( } 1 \text { ), flies ( } 2 \text { : dead), numerous } \\
\text { aphids on lettuce, numerous scale insects on pineapples }\end{array}$ \\
\hline & Martin de Viviès, & 32 & 2153 & $85.2 \%$ & $14.8 \%$ & $<0.1 \%$ & $\begin{array}{l}\text { Total: } 17+\text { Earwigs ( } 2 \text { : alive), butterfly ( } 1 \text { : dead), } \\
\text { caterpillars ( } 11: \text { alive), flies ( } 2 \text { : dead), fly larva }(1), \\
\text { numerous scale insects on pineapples }\end{array}$ \\
\hline Australia ${ }^{b}$ & All stations & 25 & 2094 & $89.1 \%$ & $10.9 \%$ & $0 \%$ & $\begin{array}{l}\text { Total: } 15 \text {. Including: thrips (alive), white flies (2: alive), } \\
\text { caterpillar (1) }\end{array}$ \\
\hline Japan & Syowa & 17 & $241 \mathrm{~kg}$ & $85.5 \%$ & $12.4 \%$ & $2.1 \%$ & None recorded \\
\hline Mean $( \pm S D)$ & & & & $\begin{array}{l}87.8 \% \\
( \pm 4.2)\end{array}$ & $\begin{array}{l}11.8 \% \\
( \pm 4.2)\end{array}$ & $\begin{array}{l}0.4 \% \\
( \pm 0.8)\end{array}$ & \\
\hline
\end{tabular}

a Macro-invertebrates were found predominantly on leafy produce, such as cabbage, lettuce, cauliflowers and pineapples.

b Food items examined in Hobart, before the voyage to the Antarctic region (Casey, Mawson, Davis and Macquarie Island stations).

Table 3

Extent of microbial infection on produce following transportation to research stations in the Antarctic region.

\begin{tabular}{|c|c|c|c|c|c|c|}
\hline \multirow[t]{2}{*}{ Station $^{\mathrm{a}}$} & \multirow[t]{2}{*}{ No./weight of items examined } & \multicolumn{5}{|c|}{ Surface area of food with microbial infection (\%) } \\
\hline & & $0 \%$ & $1-25 \%$ & $26-50 \%$ & $51-75 \%$ & $76-100 \%$ \\
\hline Rothera & 3608 & $66.8 \%$ & $27.6 \%$ & $3.7 \%$ & $1.6 \%$ & $0.3 \%$ \\
\hline SANAE IV & 1430 & $84.1 \%$ & $10.4 \%$ & $4.2 \%$ & $1.2 \%$ & $0.1 \%$ \\
\hline Port-aux-Français & 1965 & $80.7 \%$ & $18.8 \%$ & $0.4 \%$ & $0 \%$ & $0.2 \%$ \\
\hline Martin de Viviès & 2153 & $72.6 \%$ & $25.6 \%$ & $1.8 \%$ & $0.1 \%$ & $0 \%$ \\
\hline Syowa & $241 \mathrm{~kg}$ & $54.4 \%$ & $16.6 \%$ & $24.9 \%$ & $4.1 \%$ & $0 \%$ \\
\hline \multirow[t]{2}{*}{ Mean $( \pm \mathrm{SD})$} & & $71.7 \%$ & $19.8 \%$ & $7.0 \%$ & $1.4 \%$ & $0.1 \%$ \\
\hline & & $( \pm 11.8)$ & $( \pm 7.0)$ & $( \pm 10.1)$ & $( \pm 1.7)$ & $( \pm 0.1)$ \\
\hline
\end{tabular}

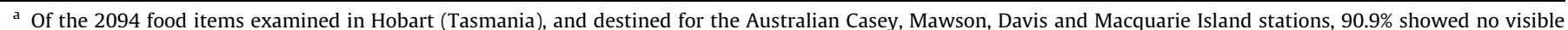
fungal infection and $9.1 \%$ showed some evidence of infection (between $1 \%$ and $100 \%$ of surface area infected).

Thysanoptera, Aleyrodidae, Lepidoptera, Arachnida (Araneomorphae), Dermaptera, Hemiptera (Aphididae), Coleoptera (including Curculionoidea), and Diptera (including Drosophilidae and Sciaridae) (see Table 2 for more details). Overall, approximately $28 \%$ of food items had visible microbial infection that resulted in some decomposition and, depending upon the national operators, between $0.6 \%$ and $29 \%$ (mean $8.5 \%$ ) had more than $25 \%$ surface rot, which in some cases rendered the item so unappealing that it would be considered inedible (Table 3 ).

\subsection{Identification of fungi on fresh foods}

Nineteen different species of fungi were isolated from fresh foods imported to Rothera Research Station (Antarctic Peninsula) and Syowa Station (continental Antarctica), with many of these represented by earlier records from isolates made in the Antarctic region (Table 4 ).

\subsection{Invertebrate transport with fresh food}

Presence of flying insects in the food storage bays at Rothera Research Station largely corresponded with the period of ship and air operations at the station (Fig. 2). In addition, individual or small numbers of flies within aircraft cabins have been reported on a number of occasions when fresh foods have been in transit to Rothera Research Station (Frenot et al., 2005; K. Hughes pers. obs.). The number of insects caught per month was highest (70) following the major ship resupply of the station in late December 2005, when the station population was high and fresh food consumption was close to its greatest level for the year. During the austral winter months when ship and aircraft operations ceased, almost no flying insects were caught. The only exception was August 2005, when a single insect was recorded, which corresponded with an emergency medical evacuation that necessitated a brief visit by an aircraft, which also brought fresh food supplies to the over-wintering population on station.

\section{Discussion}

The data presented here show clearly that the importation of fresh foods has the potential to transport soil, microorganisms and invertebrates that originate from locations throughout the world into the Antarctic region. Food items with some soil on their surface accounted for c. $12 \%$ of imported fresh produce. Although estimates vary widely on the number of bacteria, fungi, protozoa, viruses and other microorganisms in soils, the presence of soil in any amount poses a biosecurity risk as demonstrated here. Each gram of soil could contain over a billion bacteria (Whitman et al., 1998) with up to several tens of thousands of species potentially identifiable using molecular techniques (see Dunbar et al., 2002; Schloss and Handelsman, 2006 and references therein). Using data from our study, if we assume that $12 \%$ of the food varieties that were sourced from $c$. 130 locations had associated soil, then at least 16 different soils were introduced to the Antarctic region. Assuming a similar level of importation for all 28 nations currently operating in the Antarctic region, then approximately 90 different soils, if not substantially more, may be introduced to the area annually, 
Table 4

Records of fungal species isolated in this study from within the Antarctic region.

\begin{tabular}{|c|c|c|c|c|c|c|c|}
\hline \multirow[t]{2}{*}{ No. } & \multirow[t]{2}{*}{ Fungal identification } & \multirow{2}{*}{$\begin{array}{l}\text { Source } \\
\text { food }\end{array}$} & \multirow[t]{2}{*}{ Provenance } & \multicolumn{3}{|c|}{ Antarctic region } & \multirow[t]{2}{*}{ Notes } \\
\hline & & & & $\begin{array}{l}\text { Sub- } \\
\text { Antarctic }\end{array}$ & $\begin{array}{l}\text { Antarctic } \\
\text { Peninsula }\end{array}$ & $\begin{array}{l}\text { Continental } \\
\text { Antarctica }\end{array}$ & \\
\hline 1 & $\begin{array}{l}\text { Penicillium solitum var. crustosum } \\
\text { (Thom) }\end{array}$ & Avocado & Uruguay $^{a}$ & & & レ & $\begin{array}{l}\text { Known in Antarctica from lake microbial mats and } \\
\text { environmental samples }\end{array}$ \\
\hline 2 & $\begin{array}{l}\text { Muscicillium theobromae (Turconi) } \\
\text { Zare \& W. Gams. (syn. Verticillium } \\
\text { theobromae) }\end{array}$ & Peach & Brazil $^{a}$ & & & & Not reported \\
\hline 3 & Mucor sp. & Peach & Brazil ${ }^{a}$ & レ & $\boldsymbol{}$ & レ & Genus common \\
\hline 4 & $\begin{array}{l}\text { Aspergillus versicolor (Vuill.) Tirab. } \\
\text { agg. }\end{array}$ & Peach & Brazil $^{a}$ & $\boldsymbol{r}$ & & レ & $\begin{array}{l}\text { Numerous reports from various environmental } \\
\text { sources }\end{array}$ \\
\hline 5 & $\begin{array}{l}\text { Aureobasidium pullulans (de Bary) G. } \\
\text { Arnaud. }\end{array}$ & Grapes & $\mathrm{USA}^{\mathrm{b}}$ & $\boldsymbol{V}$ & レ & レ & $\begin{array}{l}\text { Numerous reports from various environmental } \\
\text { sources }\end{array}$ \\
\hline 6 & Trichoderma atroviride Bissett. & Broccoli & Chile $^{\text {a }}$ & & & & $\begin{array}{l}\text { Species not reported, genus found throughout } \\
\text { Antarctica region }\end{array}$ \\
\hline 7 & $\begin{array}{l}\text { Fusarium graminearum Schwabe. } \\
\text { agg. }\end{array}$ & $\begin{array}{l}\text { Cauliflower } \\
\text { Lettuce }\end{array}$ & $\begin{array}{l}\text { Chile }^{\mathrm{a}} \\
\text { Falkland } \\
\text { Islands }^{\mathrm{a}}\end{array}$ & & & & $\begin{array}{l}\text { Species not reported, genus found throughout } \\
\text { Antarctica region from soil, water, Deschampsia } \\
\text { antarctica and other plant material }\end{array}$ \\
\hline 8 & $\begin{array}{l}\text { Ascomycota gen. indet. Homology } \\
\text { was insufficient to provide a name, } \\
\text { even to genus. }\end{array}$ & Ginger & Argentina ${ }^{a}$ & & & & \\
\hline 9 & Penicillium expansum Link. & Ginger & Argentina ${ }^{a}$ & レ & $\boldsymbol{\nu}$ & レ & Found widely in air, soil and historic huts \\
\hline 10 & $\begin{array}{l}\text { Penicillium sp. Top matches at } 100 \% \\
\text { homology to } P \text {. brevicompactum and } \\
\text { P. biourgeanum. }\end{array}$ & Garlic & China $^{a}$ & レ & $\boldsymbol{V}$ & $\boldsymbol{\nu}$ & $\begin{array}{l}\text { P. biourgeanum not reported from Antarctica. P. } \\
\text { brevicompactum Dierckx }\end{array}$ \\
\hline 11 & $\begin{array}{l}\text { Pleospora sp. (including Stemphylium } \\
\text { anamorph) }\end{array}$ & Garlic & China $^{a}$ & レ & レ & & $\begin{array}{l}\text { Genus widely reported from sub-Antarctic, only one } \\
\text { report from the northern Antarctic Peninsula }\end{array}$ \\
\hline 12 & Alternaria alternata (Fr.) Keissl. agg. & Grapefruit & Uruguay $^{a}$ & $\boldsymbol{r}$ & レ & レ & Isolated from air samples, soil and lichens \\
\hline 13 & Botrytis cinerea Pers. agg. & Lettuce & $\begin{array}{l}\text { Falkland } \\
\text { Islands }^{\mathrm{a}}\end{array}$ & レ & $\boldsymbol{V}$ & & Reported from air and soil samples \\
\hline 14 & $\begin{array}{l}\text { Leptosphaeria maculans (Desm.) Ces. } \\
\text { \& de Not. }\end{array}$ & Cabbage & Chile $^{a}$ & & & & $\begin{array}{l}\text { Species not reported, genus found widely throughout } \\
\text { Antarctica region }\end{array}$ \\
\hline 15 & Epicoccum nigrum Link. & Pineapple & Brazil $^{\text {a }}$ & & $\boldsymbol{}$ & 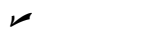 & Isolated from air, lichen and soil \\
\hline 16 & Penicillium mali & $\begin{array}{l}\text { Garlic, } \\
\text { Ginger, } \\
\text { Honeydew }\end{array}$ & $\begin{array}{l}\text { Japan }^{\mathrm{c}} \\
\text { Australia }^{\mathrm{c}}\end{array}$ & & & & $\begin{array}{l}\text { Species not reported. Genus common in the Antarctic } \\
\text { region }\end{array}$ \\
\hline 17 & Penicillium corylophium & Ginger & Japan $^{\mathrm{c}}$ & & レ & $\boldsymbol{}$ & Isolated from soil and environmental samples \\
\hline 18 & Mucor hiemalis $f$. hiemalis, & Carrot & Japan $^{\mathrm{c}}$ & $\boldsymbol{\nu}$ & $\boldsymbol{\nu}$ & レ & Isolated from soil and Deschampsia antarctica \\
\hline 19 & Trichoderma hamatum & Carrot & Japan $^{\mathrm{c}}$ & & & & $\begin{array}{l}\text { Species not reported, genus found in continental and } \\
\text { peninsular Antarctica }\end{array}$ \\
\hline
\end{tabular}

a RRS James Clark Ross: Foods collected in the Falkland Islands (21-29 November, 2007) and shipped to Rothera Research Station (9 December 2007).

b De Havilland DASH 7: fresh foods collected in Punta Arenas and flown to Rothera Research Station (25 November 2007 - transit time 5-6 h).

c Icebreaker Shirase: foods collected in Tokyo and Fremantle (western Australia) and shipped to Syowa Station (transit time $c$. 7 and 3 weeks, respectively).

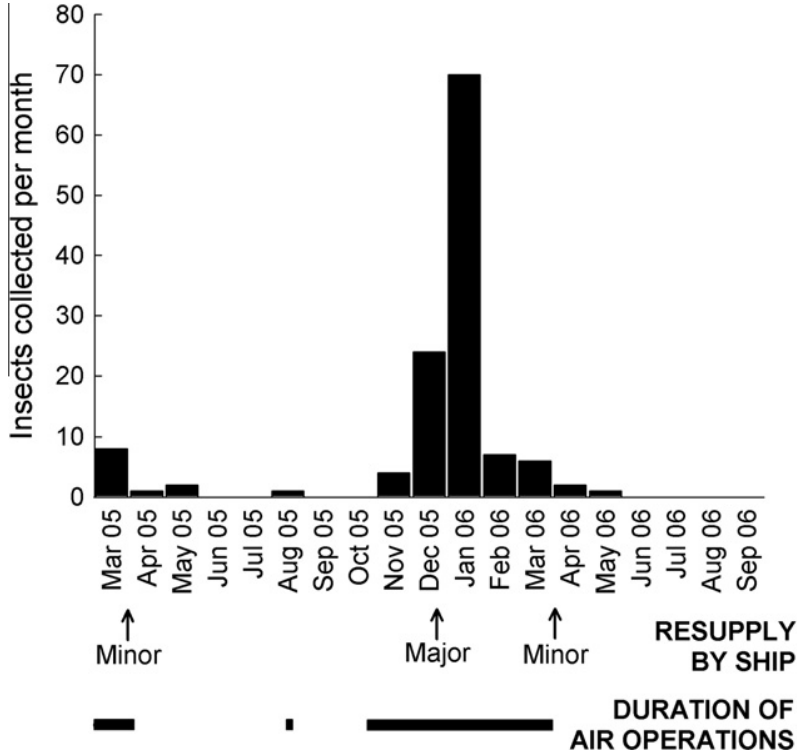

Fig. 2. Flying insects caught in UV electric insect killers in Rothera Research Station food storage bays. each containing potentially thousands of microbial strains new to the Antarctic region. The consequences of such introductions are, as yet, unknown, but are likely to impact upon existing microbial community structure, with associated implications for biogeochemistry and ecosystem functioning, and may cause disease in native plants and invertebrates (Wynn-Williams, 1996; Cowan and Ah Tow, 2004). Lateral gene transfer may also occur between indigenous and introduced species leading to 'genetic pollution' of Antarctic microbial communities (Smith et al., 1993; Smith and McFeters, 1998).

The identified fungi were all taxa commonly found on fresh foods or associated soil and foliage. Most of the species identified are known to be generalists with a wide-ranging physiological plasticity and cosmopolitan distribution outside Antarctica. Saprotrophs dominated, although Fusarium graminearum and Muscicillium theobromae can cause vascular wilts in many different plants world-wide (Stoyan et al., 2003; Qin et al., 2006). Most of the fungi isolated were conidial ascomycetes that can liberate air borne asexual spores, so for these organisms (such as Penicillium sp.) there is a high possibility of subsequent dispersion into the environment. Human importation of fresh fruits and vegetables to Antarctica may select unintentionally for fungal phytopathogens. The term 'fresh food' can also be misleading as there were foods, such as pears and onions, that had been in cool storage for many months 
Table 5

Measures to reduce the risk of non-native species introductions to the Antarctic region associated with fresh foods.

1. Planning

(a) When planning the purchase of food types for consumption in the Antarctic region, consideration should be given to banning, or limiting seasonally, the importation of fresh foods that are likely to have high propagule loads, to stations in environments where non-native species are likely to be able to become established

2. Food sourcing and preparation for transportation

(a) Consideration should be made of the transit time between the port where food supplies are taken on and the Antarctic destination. If possible, fresh food should be transported when voyage times are at their shortest. If long transit times are predicted, only fresh foods likely to remain unspoiled (e.g. apples and potatoes) should be carried and foods prone to rapid spoiling avoided

(b) Use contract management strategies to ensure delivery of clean produce from suppliers:

(i) Ensure the produce has good post-harvest condition and generally high levels of agricultural cleanliness (e.g. such as soil-free food items and boxes)

(ii) Ensure underground or near-ground crops (e.g. root vegetables or cabbages and lettuces) have been cleaned to remove attached soil and, especially in the case of cabbages and lettuces, associated invertebrates

(iii) Instruct suppliers to undertake checks for soil and invertebrates before leaving the source country. Check, in particular, leafy fresh food varieties that may be more likely to trap soil and invertebrates

(c) Avoid sourcing out of season foods, which may have already been cold-stored for many months, as they may be more susceptible to spoilage and risk carrying cold-selected microorganisms

(d) Package fruit and vegetables to contain any remaining soil or invertebrates, so propagules can be disposed of in an appropriate way later

(e) If feasible, irradiate or fumigate produce before exportation to Antarctica

(f) Immediately before transportation, foods should be checked to ensure they are free of soil and invertebrates and are not excessively decayed. If any soil or viable biological organisms are found, the contaminated food should not be accepted for transportation or should be cleaned and then re-inspected

(g) Ensure produce transported by air is free of invertebrates, as short transit times increases the likelihood of them arriving in Antarctica in a viable state

h) If aircraft or ship departure to Antarctica is delayed, ensure that any fresh foods that have decayed during the delay period are removed before further transportation

3. Food in transit to the Antarctic region

(a) Any live insects found within the ship or aircraft cabin should be destroyed

(b) Aircraft and ships should carry insecticide spray to eradicate any insects found

(c) When transporting food by ship:

(i) Produce should be stored in a refrigerator or cool room to reduce microbial growth and food spoilage

(ii) Insect traps should be installed both within and immediately outside refrigerator or cool room areas

(iii) Insect traps should be installed in all kitchen areas as well as areas that are warm and have potential invertebrate food sources (e.g. mess areas)

(d) Biosecurity precautions should be extended to ships conducting landings within the Antarctic region to prevent distribution of non-native species to terrestrial Antarctic habitats directly from ships

4. Food checks either on arrival or immediately before off-loading

(a) Before off-loading or on arrival, fresh produce should be examined for excessively decomposed food items. If found, such produce should not be off-loaded but sealed immediately in burnable packaging for transport to an incinerator and then incinerated, dumped out to sea in accordance with the provisions of the International Convention for the Prevention of Pollution from Ships (MARPOL 73/78; Annex IV: Prevention of pollution by sewage from ships, and Annex V: Prevention of pollution by garbage from ships) or returned to the host port for disposal using recognised port waste disposal facilities

(b) If the produce has already been off-loaded it should be contained immediately and either incinerated on the station or returned to the ship or aircraft as soon as possible for disposal as detailed in $4($ a)

(c) Before off-loading or on arrival, food should be examined for invertebrates and any invertebrates found should be killed immediately

(d) The inspection of fresh foods within containers that have already been landed should take place in a closed room with a sealed floor

(e) During transportation of produce between ship/aircraft and the station, fresh foods and their containers should not be left outside

5. $\quad$ Fresh food storage on station or in field huts

(a) Fresh fruit and vegetables should be stored and sealed in specified areas containing UV lamp electric fly killers and insect sticky traps

(b) Boxes/bags of food items, including non-irradiated eggs, should be stored in washable spill-trays, to capture soil or organic material that falls off the produce, and/ or stored in rooms with solid washable floors

(c) The food storage area, spill-trays and floors should be cleaned regularly with an antimicrobial cleaning product/disinfectant (e.g. Virkon ${ }^{\circledR}$ or dilute bleach). No runoff from floors should be allowed outside to the environment

(d) Transport of fresh food between station buildings should be within sealed containers (boxes, plastic bags, etc.)

6. Food waste disposal

(a) Fresh food wastes should be disposed of by incineration or made sterile through autoclaving or cooking before disposal

(b) Disposal of uncooked food waste through the kitchen grey water or sewage system should be avoided if no post-treatment sterilisation exists, as this may release non-native microorganisms to the environment

(c) Ensure all boxes, crates, bags and other packaging is disposed off in a way that prevents release of any associated non-native organisms, e.g. by incineration or containment and shipping

prior to entering the transport pathway, and so the fungi could have arrived in the Antarctic 'pre-selected' for low temperature tolerance.

In this study, the foods that underwent microbiological investigations originated from nine countries within Asia, Australasia, and North and South America. Roughly two thirds of the strains were recorded previously from at least one location within the Antarctic region, and of those strains, half were recorded previously from all three Antarctic regions. Penicillium mali and Trichoderma hamatum were never previously reported from continental Antarctica, yet introduced to Syowa Station, and $F$. graminearum, Trichoderma atroviride, Aspergillus versicolor, M. theobromae, and Penicillium solitum were not recorded from the Antarctic Peninsula, yet introduced to Rothera Research Station. It is likely that many of these species may exist already in Antarctica, but have simply not been reported due to a lack of microbial biodiversity data throughout the Antarctic region. More than 1000 species of fungi have been reported from the Antarctic and sub-Antarctic region. Most are species known from elsewhere in the world, particularly from cool temperate and alpine habitats, with few considered truly endemic to the Antarctic region (Bridge et al., 2008; Bridge and Hughes, 2010).

It must be remembered that a species can only be classified as 'native' or 'non-native' when considered in the context of a specific location (and a specific time). Human-introduced microbial species may be native in one region of Antarctica but non-native in other areas, although strain characteristics, such as the range of temperatures over which growth can occur, are likely to be different. 
Although the microbial diversity associated with a given food item may be fixed, it may contain a different proportion and sub-set of non-native microbial species, depending upon the diversity of the indigenous microbiota in the location it is introduced to. For example, in our study produce for Australia's four stations in the subAntarctic and continental Antarctica was sourced from the same suppliers, and often delivered during the same ship voyage. The proportion of non-native microorganisms associated with that produce will depend upon which microbiota exist already at each of the four individual station locations.

This spatial component may be taken further as potential microbial impacts may also depend upon the physical, chemical and biological characteristics of the new location. For example, the fungus Botryotinia fuckeliana (conidial state: Botrytis cinerea; also isolated in our study from partially decomposed lettuce) was probably introduced to sub-Antarctic Marion Island on fresh vegetables (Klopper and Smith, 1998; Frenot et al., 2005) and subsequently identified as the pathogen associated with the recent decline of Pringlea antiscorbutica (Kerguelen cabbage). Nevertheless, this fungal species is present on South Georgia and Macquarie Island (sub-Antarctic) and King George Island (Antarctic Peninsula) which are outside the distribution range of $P$. antiscorbutica and consequently equivalent impacts are not observed (see Bridge et al., 2008).

Microorganisms are not the only biological group that can be transported in association with foods. Our results show a close link between the numbers of live non-native flying insects on station and the level of logistic activity whereby foodstuffs are transported to the station. Frenot et al. (2005) reported that many of the nonnative invertebrates present on the sub-Antarctic islands are known to have been imported in association with food stores, although formal reports in the scientific literature of these introductions are scarce (though see Hänel et al., 1998). In separate incidents, Lycoriella sp. (black fungus midge) were introduced to Casey and Rothera Research Stations, where they were able to establish synanthropically within the sewage system and alcohol bond, respectively (Hughes et al., 2005). The midge has been successfully eradicated at Rothera Research Station, while on-going eradication measures at Casey mean the midge is restricted to defined subfloor regions of the station. Fungus midge larvae are capable of transmitting fungal plant pathogens (Jarvis et al., 1993; Harris et al., 1996) and spores of the mycoparasite Coniothyrium minitans (Whipps and Budge, 1993) and it is possible that introduced invertebrates could carry microbial pathogens that may impact on native Antarctic biota.

Insects may readily be transported to research stations by both aircraft (Frenot et al., 2005; K. Hughes, pers. obs.) and ship. Regular surveys indicated that the non-native parasitoid wasp Aphidius matricariae was introduced to Marion Island between 2001 and 2003 , seven years after a ban on fresh produce was introduced in 1996 (Anonymous, 1996). The wasp is found at highest abundance in the area immediately adjacent to the bay where the re-supply ship lays anchor and, because no fresh produce is permitted ashore in the years immediately preceding its discovery, it is thought that the source of propagules was parasitized aphids on fresh produce aboard the ship which subsequently colonized the island when the ship was at anchor (Lee et al., 2007).

\section{Conclusions}

If obligations to conserve and protect indigenous Antarctic biota are to be fulfilled, as stipulated by the Protocol on Environmental Protection to the Antarctic Treaty and national legislation (reviewed by de Villiers et al., 2006; Rogan-Finnemore, 2008), then routes by which anthropogenic introductions occur need to be examined, quantified and effective mitigation measures adopted (de Villiers and Cooper, 2008). Although the only way to reduce propagule pressure to zero along the food pathway would be to stop the transport of fresh produce into a region (as has been done at the Prince Edward Islands and Heard Island), simple practical measures such as minimising the transport of unwashed produce, using refrigerated transport to retard the development of microbiota and reducing the amount of leafy and out of season produce would likely dramatically reduce propagule pressure (a provisional list of such measures is provided in Table 5). However, only when these measures are adopted by organisations operating across the whole region will Antarctica's biosecurity be enhanced and the current risk to the native biota be reduced effectively.

\section{Acknowledgements}

We thank Jennie Whinam, Maurice Hulle, Bart Van de Vijver, Sylvie Geiger, David Hedding, Sarah Fayed and John Loines for assistance with the food inspection survey, Peter Fretwell for map preparation, Alan Buddie, Lukasz Tymo, Thelma Caine, Tamotsu Hoshino, Masanobu Ito and Ryo Murakamifor fungal identifications and three anonymous reviewers for their helpful comments. This paper is a contribution to the International Polar Year 'Aliens in Antarctica' and SCAR EBA (Evolution and Biodiversity in Antarctica) research programmes and the British Antarctic Survey's Polar Science for Planet Earth core programme EO-LTMS (Environment Office-Long Term Monitoring and Survey).

\section{References}

Anonymous, 1996. Prince Edward Islands Management Plan. Department of Environmental Affairs and Tourism, Pretoria.

Bergstrom, D.M., Chown, S.L., 1999. Life at the front: history, ecology and change on Southern Ocean Islands. Trends Ecol. Evol. 14, 472-477.

Bridge, P.D., Hughes, K.A., 2010. Conservation issues for Antarctic fungi. Mycol Balcanica 7, 11-14.

Bridge, P.D., Spooner, B.M., Roberts, P.J., 2008. Non-lichenized fungi from the Antarctic region. Mycotaxon 106, 485-490.

Chwedorzewska, K.J., 2008. Poa annua L. in Antarctic: searching for the source of introduction. Polar Biol. 31, 263-268.

Cowan, D.A., Ah Tow, L., 2004. Endangered Antarctic microbial communities. Annu. Rev. Microbiol. 58, 649-690.

Curran, J., Driver, F., Ballard, J.W.O., Milner, R.J., 1994. Phylogeny of Metarhizium: analysis of ribosomal DNA sequence data. Mycol. Res. 98, 547-552.

De Villiers, M.S., Cooper, J., Carmichael, N., Glass, J.P., Liddle, G.M., McIvor, E., Micol T., Roberts, A., 2006. Conservation management at Southern Ocean Islands: towards the development of best-practice guidelines. Polarforschung 75,113 131.

De Villiers, M.S., Cooper, J., 2008. Conservation and management. In: Chown, S.L., Froneman, P.W. (Eds.), The Prince Edward Islands: Land-Sea Interactions in a Changing Ecosystem. African SunMedia, Stellenbosch, pp. 301-330.

Drake, J.M., Lodge, D.M., 2004. Global hot spots of biological invasions: evaluating options for ballast-water management. Proc. R. Soc. Lond. B Biol. 271, 575-580.

Dunbar, J., Barns, S.M., Ticknor, L.O., Kuske, C.R., 2002. Empirical and theoretical bacterial diversity in four Arizona soils. Appl. Environ. Microbiol. 68, 30353045 .

Frenot, Y., Chown, S.L., Whinam, J., Selkirk, P.M., Convey, P., Skotnicki, M., Bergstrom, D.M., 2005. Biological invasions in the Antarctic: extent, impacts and implications. Biol. Rev. 80, 45-72.

Hänel, C., Chown, S.L., Davies, L., 1998. Records of alien insect species from subAntarctic Marion and South Georgia Islands. Afr. Entomol. 6, 366-369.

Harris, M.A., Gardner, W.A., Oetting, R.D., 1996. A review of the scientific literature on fungus gnats (Diptera: Sciaridae) in the genus Bradysia. J. Entomol. Sci. 31 252-276.

Hughes, K.A., Convey, P., 2010. The protection of Antarctic terrestrial ecosystems from inter- and intra-continental transfer of non-indigenous species by human activities: a review of current systems and practices. Global Environ. Change 20 96-112.

Hughes, K.A., Walsh, S., Convey, P., Richards, S., Bergstrom, D.M., 2005. Alien fly populations established at two Antarctic research stations. Polar Biol. 28, 568570.

Hughes, K.A., Convey, P., Maslen, N.R., Smith, R.I.L., 2010a. Accidental transfer of non-native soil organisms into Antarctica on construction vehicles. Biol. Invas. 12, 875-891.

Hughes, K.A., Lee, J.E., Ware, C., Kiefer, K., Bergstrom, D.M., 2010b. Impact of anthropogenic transportation to Antarctica on alien seed viability. Polar Biol. 33, 1123-1130 
Hull, B.B., Bergstom, D.M., 2006. Antarctic terrestrial and limnetic ecosystem conservation and management. In: Bergstrom, D.M., Convey, P., Huiskes, A.H.L. (Eds.), Trends in Antarctic Terrestrial and Limnetic Ecosystems. Springer, Dordrecht, The Netherlands, pp. 317-340.

Jabour, J., 2009. National Antarctic programs and their impact on the environment. In: Kerry, K.R., Riddle, M.J. (Eds.), Health of Antarctic Wildlife-A Challenge for Science and Policy. Springer, Heidelberg, pp. 211-229.

Jacks, D.S., Pendakur, K., 2008. Global trade and the maritime transport revolution. J. Econ. Hist. 68, 614

Jarvis, W.R., Shipp, J.L., Gardiner, R.B., 1993. Transmission of Pythium aphanidermatum to greenhouse cucumber by the fungus gnat Bradysia impatiens (Diptera, Sciaridae). Ann. Appl. Biol. 122, 23-29.

Johnston, A., Booth, C. (Eds.), 1983. The Plant Pathologist's Pocketbook, second ed Commonwealth Mycological Institute, Kew, pp. 439.

Jones, P.D., 1995. Recent variations in mean temperature and the diurnal temperature-range in the Antarctic. Geophys. Res. Lett. 22, 1345-1348.

Kerry, K.R., Riddle, M.J. (Eds.), 2009. Health of Antarctic Wildlife - A Challenge for Science and Policy. Springer, Heidelberg.

King, J.C., Comiso, J.C., 2003. The spatial coherence of interannual temperature variations in the Antarctic Peninsula. Geophys. Res. Lett. 30, 1040.

Klopper, F.J., Smith, V.R., 1998. First report of Botryotinia fuckeliana on Kerguelen cabbage on the sub-Antarctic Marion Island. Plant Dis. 82, 710.

Lamers, M., 2009. The Future of Tourism in Antarctica: Challenges for Sustainability. Ph.D. Thesis. University of Maastricht. ISBN 978-90-5278-869-2, 235pp.

Lee, J., Slabber, S., Jansen van Vuuren, B., van Noort, S., Chown, S.L., 2007 Colonisation of sub-Antarctic Marion Island by a non-indigenous aphid parasitoid Aphidius matricariae (Hymenoptera, Braconidae). Polar Biol. 30, 1195-1201.

Lee, J.E., Chown, S.L., 2009a. Breaching the dispersal barrier to invasion: quantification and management. Ecol. Appl. 19, 1944-1959.

Lee, J.E., Chown, S.L., 2009b. Quantifying the propagule load associated with the construction of an Antarctic research station. Antarct. Sci. 21, 471-475.

Molina-Montenegro, M.A. Carrasco-Urra, F., Rodrigo, C., Valladares, F., Gianoli, E. 2010. Plant invasions in the Antarctic continent: vectors and consequences. In: Poster at Scientific Committee on Antarctic Research Open Science Conference, Buenos Aires, Argentina (Unpublished).

Poland, J.S., Riddle, M.J., Zeeb, B.A., 2003. Contaminants in the Arctic and Antarctic: a comparison of sources, impacts, and remediation options. Polar Rec. 39, 369383.

Procheş, S., Wilson, J.R.U., Vamosi, J.C., Richardson, D.M., 2008. Plant diversity in the human diet: weak phylogenetic signal indicates breadth. Bioscience 58, 151159.

Qin, Q.-M., Vallad, G.E., Wu, B.M., Subbarao, K.V., 2006. Phylogenetic analyses of phytopathogenic isolates of Verticillium spp. Phytopathology 96, 582-592.

Rogan-Finnemore, M. (Ed.), 2008. Non-native species in the Antarctic. In: Proceedings, Gateway Antarctica Special Publication Series 0801, Christchurch, New Zealand.
Schloss, P.D., Handelsman, J., 2006. Toward a census of bacteria in soil. PLoS Comput. Biol. 2, e92. doi:10.1371/journal.pcbi.0020092.

Scientific Committee for Antarctic Research (SCAR), 2010. Preliminary results from the International Polar Year programme: Aliens in Antarctica. Antarctic Treaty Consultative Meeting XXXIII, Committee for Environmental Protection XIII, Working Paper 04. 3-14 May, 2010, Punta del Este, Uruguay.

Smith, J.J., McFeters, G.A., 1998. Microbiological issues of sewage disposal from Antarctic bases: dispersion, persistence, pathogens, and "genetic pollution". In: Kerry, K., Riddle, M., Clark, J. (Eds.), Disease of Antarctic Wildlife: A Report on the 'Workshop on Diseases of Antarctic Wildlife'. Australian Antarctic Division, Kingston, Tasmania, pp. 56-57.

Smith, J.J., Howington, J.P., McFeters, G.A., 1993. Plasmid maintenance and expression in Escherichia coli exposed to the Antarctic marine environment. Antarct. J. US 28, 123-124.

Smith, R.I.L., Richardson, M., 2011. Fuegian plants in Antarctica: natural or anthropogenically assisted immigrants? Biol. Invasions. doi:10.1007/s10530010-9784-x.

Steig, E.J., Schneider, D.P., Rutherford, S.D., Mann, M.E., Comiso, J.C., Shindell, D.T., 2009. Warming of the Antarctic ice-sheet surface since the 1957 International Geophysical Year. Nature 457, 459-462.

Stoyan, R.P., Edwards, S.G.C.H.M., Jenkinson, P., 2003. Strategies for the control of Fusarium head blight in cereals. Plant Pathol. 44, 207-238.

Turner, J., Colwell, S.R., Marshall, G.J., Lachlan-Cope, T.A., Carleton, A.M., Jones, P.D., Lagun, V., Reid, P.A., Iagovkina, S., 2005. Antarctic climate change during the last 50 years. Int. J. Climatol. 25, 279-294.

Turner, J., Overland, J.E., Walsh, J.E., 2007. An Arctic and Antarctic perspective on recent climate change. Int. J. Climatol. 27, 277-293.

Vaughan, D.G., Marshall, G.J., Connolley, W.M., Parkinson, C., Mulvaney, R., Hodgson, D.A., King, J.C., Pudsey, C.J., Turner, J., 2003. Recent rapid regional climate warming on the Antarctic Peninsula. Clim. Change 60, 243-274.

Vezina, S., 2005. Environmental management in a global economy. CIM Bull. 98, 1091.

Whinam, J., Chilcott, N., Bergstrom, D.M., 2005. Subantarctic hitchhikers: expeditioners as vectors for the introduction of alien organisms. Biol. Conserv. 121, 207-219.

Whipps, J.M., Budge, S.P., 1993. Transmission of the mycoparasite Coniothyriummintans by collembolan Folsomia candida (Collembola, Entomobryidae) and glasshouse Sciarid Bradysia sp. (Diptera, Sciaridae). Ann. Appl. Biol. 123, 165171.

Whitman, W.B., Coleman, D.C., Wiebe, W.J., 1998. Prokaryotes: the unseen majority. Proc. Nat. Acad. Sci. 95, 6578-6583.

Wynn-Williams, D.D., 1996. Antarctic microbial diversity: the basis of polar ecosystem processes. Biodivers. Conserv. 5, 1271-1293. 